Ind. Health, 1975, 13, 115.

\title{
HEMATOLOGICAL AND NEURO-MUSCULAR RESPONSE OF WORKERS EXPOSED TO LOW CONCENTRATION OF TOLUENE VAPOR
}

\author{
Toshio MATSUShITA, Yoshiki ARIMATSU, Atsushi UEDA, \\ Kazuko SATOH and Shigeru NOMURA \\ Department of Public Health, Kumamoto University \\ Medical School, Honjo, Kumamoto
}

(Received April 4, 1975)

To obtain basic data on TLV for toluene and early findings of toluene intoxication, some investigations were undertaken for female shoe makers exposed to low concentration of toluene vapor ranging about 60 to $100 \mathrm{ppm}$.

Subjective symptoms of the exposed group were significantly different from those of control group on sensation of general weakness, dysmenorrhoea, itching and dermatitis of hands and feeling uneasy about solvent vapor. In hematological findings, there was no significant difference in both groups except for appearance rate of Mommsen's toxic granules in peripheral neutrophiles. Mean value and standard deviation of hippuric acid concentration in the urine were $3.26 \pm 0.82 \mathrm{mg} / \mathrm{ml}$ in exposed group and $0.35 \pm 0.24 \mathrm{mg} / \mathrm{ml}$ in control group, which revised at 1.024 by specific gravity.

There were some significant differences between them in neurologic and muscular function tests such as abnormal tendon reflex, grasping power of not-dominant in the whip hand, decrease in tapping tempo, agility of the fingers, and so forth.

These findings suggest that TLV of $100 \mathrm{ppm}$ for toluene adopted in Japan Association of Industrial Health should be reconsidered.

The results of many studies on the toxic effects of toluene show that it can not cause any serious injury to the organs like benzene. It has been reported that toluene may produce some disturbance of nervous system, ${ }^{1,2)}$ changes in muscular coordination, ${ }^{3)}$ adrenocortical insufficiency,4) slight injury to the hematopoietic system ${ }^{5,6)}$ and so forth ${ }^{7,8)}$ in concentration of $200 \mathrm{ppm}$ or over.

But, there is some difference on TLV for toluene adopted among countries. Nevertheless, little work has been done to serve for this problem and to decide early toluene intoxication. To clarify these problems, a health survey on shoe-makers exposed to low concentration of toluene vapor was conducted. 


\section{T. MATSUSHITA, Y. ARIMATSU, A. UEDA, K. SATOH \& S. NOMURA}

\section{Materials AND Methods}

\section{Subjects}

The cases for this study were 38 female workers engaged in the process of shoe making who had been used glue containing mainly toluene and slight gasoline (exposed group), and 16 female workers in the same plant who had never exposed to any solvent (control group).

The mean age of exposed group was $20.7 \pm 5.2$, and the average duration of the workers exposed to the solvents was 3 years and 4 months. The age of the control group was almost equal to the exposed group. Women who were pregnant or had delivery during 12 months previous to the survey were excluded.

\section{Environmental conditions}

There were air conditioning and some local ventilation in the workroom of the exposed group. The toluene concentration in the air determined by Kitagawa's detector were between 15 and $100 \mathrm{ppm}$, which was about 60 to $70 \mathrm{ppm}$ in the average value at both February and September, and 10 to $200 \mathrm{ppm}$, i.e., $100 \mathrm{ppm}$ in average at August. In a few working place, gasoline of ranging 20 to $50 \mathrm{ppm}$, about $20 \mathrm{ppm}$ in the average value, were detected in this environment by Kitagawa's detector.

\section{Physical and laboratory tests}

Subjective symptoms of the workers were checked up by questionnaire method of our own making and CMI. Standard methods were used for usual physical and laboratory tests such items as hematological tests $(\mathrm{Gb}, \mathrm{Hb}, \mathrm{Ht}, \mathrm{WBC}$ and appearance rate of Mommsen's toxic granules in the neutrophiles ${ }^{9)}$ ), liver function tests (SGOT, SGPT, TTT, ZTT and analysis of serum proteins), urinalysis (protein, sugar, urobilinogen, bilirubin, occulted blood, keton body and hippuric acid ${ }^{10,11)}$ ), neurological and muscular function tests (tapping tempo, bloking test, agility of fingers, cold pressure, postural hypotension, grasping power and cuff test) and so forth. Decrease in tapping tempo was shown by rate of later two values to former two ones in each five tapping values. Agility of the fingers was estimated by determination of spend time for moving place of 25 bulbs using glass chopsticks. All clinical and laboratory tests were undertaken at August.

\section{RESULTS}

\section{Subjective symptoms}

As indicated in Table 1, subjective symptoms of the exposed group were apparently different from those of the control group in some complaints such as sensation of general weakness, dysmenorrhoea, itching and dermatitis of hands and feeling uneasy about solvent vapor. There was no marked difference between both groups in their histories and in the regions of CMI classified by Fukamachi's method. 


\section{TLV OF TOLUENE}

Table 1. Complaints of the workers exposed to toluene vapor.

\begin{tabular}{l|c|c}
\multicolumn{1}{c|}{ Complaint } & Exposed group & Control group \\
\hline Sensation of general weakness & $10(26) \dagger$ & $1(6)$ \\
Feeling of fatigability & $30(79)$ & $11(69)$ \\
Loss of body weight & $13(34)$ & $2(13)$ \\
Headache & $14(37)$ & $6(38)$ \\
Feeling heavy in the head & $18(47)$ & $8(50)$ \\
Nervousness & $18(47)$ & $8(50)$ \\
Frequent dizziness & $8(21)$ & $4(25)$ \\
Breath with difficulty & $7(18)$ & $1(6)$ \\
Feeling pain in the extremities & $5(13)$ & $1(6)$ \\
Easy fatigability of the extremities & $9(24)$ & $3(19)$ \\
Rigidity of the extremities & $5(13)$ & $1(6)$ \\
Tremor & $6(16)$ & $3(19)$ \\
Itching \& dermatitis of hands & $11(29) \dagger$ & $1(6)$ \\
Dysmenorrhoea & $19(50) \dagger$ & $3(19)$ \\
Feeling uneasy about solvent vapor & $17(45) \dagger+\dagger$ & $1(6)$ \\
\hline Numbers investigated & $38(100)$ & $16(100)$ \\
\hline
\end{tabular}

Each parenthesis shows the percentage to the numbers investigated.

Statistical significance $\left(\chi^{2}\right.$-test $): t(P<0.1) \quad \pi(P<0.05) \quad \pi(P<0.01)$

Table 2. Results of hematological examination. (Mean \pm S.D.)

\begin{tabular}{l|c|c}
\multicolumn{1}{c|}{ Items } & Exposed group & Control group \\
\hline Specific gravity of the whole blood & $1.0526 \pm 0.0024$ & $1.0525 \pm 0.0025$ \\
& {$[8(21)]$} & {$[4(25)]$} \\
Hemoglobin content $(\mathrm{g} / \mathrm{d} l)$ & $12.0 \pm 0.9$ & $11.9 \pm 1.1$ \\
Hematocrit $(\%)$ & {$[18(47)]$} & {$[6(38)]$} \\
White blood cell counts $\left(/ \mathrm{mm}^{3}\right)$ & $41.0 \pm 3.2$ & $41.0 \pm 3.5$ \\
Appearance rate of Mommsen's toxic & {$[2(5)]$} & {$[2(13)]$} \\
granules in the neutrophiles $(\%)$ & {$[100 \pm 1300$} & $6400 \pm 2100$ \\
\hline Numbers investigated & {$[9(24)]$} & {$[4(25)]$} \\
\hline
\end{tabular}

The brocked passages show abnormal numbers of each item and the parenthesis signify the percentage to each numbers investigated.

Statistical significance ( $t$ - and $\chi^{2}$-test): $t(P<0.05)$

\section{Hematological findings}

Table 2 represents principal results of hematological examination. There was no significant difference between exposed group and control group except for appearence rate of Mommsen's toxic granules in the neutrophiles. Abnormal appearance of Mommsen's toxic granules in the peripheral neutrophiles of the exposed group was marked in numbers and in mean value. 


\section{T. MATSUSHITA, Y. ARIMATSU, A. UEDA, K. SATOH \& S. NOMURA}

\section{Urinalysis}

There was scarcely any marked finding on the urinalysis except for excretion of hippuric acid, main metabolite of toluene. Mean value and standard deviation of hippuric acid concentration in the urine which sampled at Thursday or Friday afternoon were $3.26 \pm 0.82 \mathrm{mg} / \mathrm{ml}$ in exposed group and $0.35 \pm 0.24 \mathrm{mg} / \mathrm{ml}$ in the control group, which revised at 1.024 by specific gravity, respectively.

\section{Neurologic and muscular functions}

Main results of neurological and muscular function tests were shown in Table 3. There was some statistical significance in both groups with abnormal tendon reflex and grasping power of not-dominant in the whip hand. In Fig. 1, results of some examinations on the neuro-muscular function were shown. Significant difference in grasping power, decrease in tapping tempo and agility of the fingers in both groups were shown by application of $\mathrm{t}$-test.

Table 3. Results of neurological and muscular function tests.

\begin{tabular}{l|c|c}
\multicolumn{1}{c|}{ Items } & Exposed group & Control group \\
\hline Abnormal tendon reflex: & & \\
biceps \& triceps & $6(16)$ & $3(19)$ \\
patellar & $14(37)+t$ & $1(6)$ \\
ankle & $7(18) \dagger$ & $0(0)$ \\
Pathological reflex & $1(3)$ & $0(0)$ \\
Grasping power (not-dominant in the & $11(29) \dagger$ & $1(6)$ \\
whip hand) & $162.9 \pm 16.6$ & $168.6 \pm 17.3$ \\
Tapping tempo (M S.D.) & $6(16)$ & $2(13)$ \\
Cold pressure test & $2(5)$ & $1(6)$ \\
Postural hypotension & $5(13)$ & $1(6)$ \\
Cuff test (upper arm) & $5(13)$ & $1(6)$ \\
Dermatographism & $68.2 \pm 13.3$ & $61.8 \pm 13.7$ \\
Blocking test $(M \pm S . D).(s e c)$ & $38(100)$ & $16(100)$ \\
\hline Numbers investigated & & \\
\hline
\end{tabular}

The parenthesis show the percentage to each numbers investigated.

Statistical significance $\left(\chi_{2}\right.$ and $t$-test $): t(P<0.1) \quad \pi(P<0.05)$

\section{Correlation between duration of exposure and examination results}

There was scarcely any marked relationship with duration of exposure to toluene and principal data excluding Mommsen's toxic granules and neuro-muscular hypofunction. Correlation between duration of exposure with toluene vapor and appearance rate of abnormal findings of examination results were shown in Fig. 2. As indicated in the graph, no statistical difference between each duration of exposure and appearance rate of clinical findings was present. 


\section{TLV OF TOLUENE}

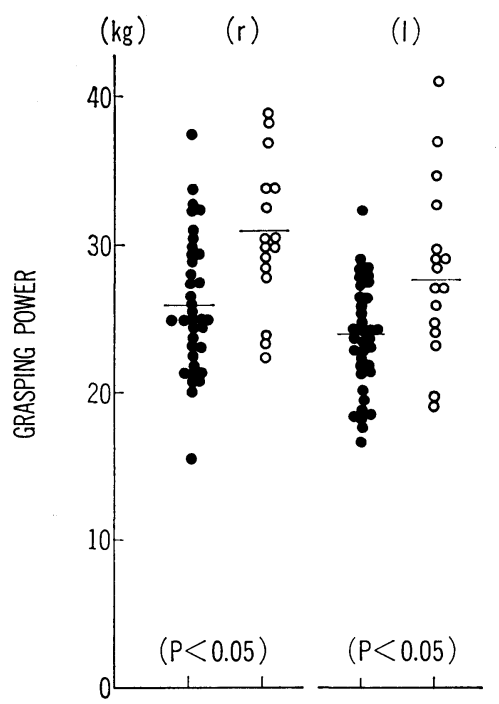

$(\%)$

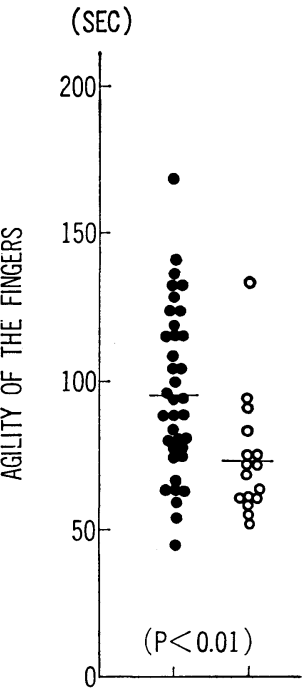

$(P<0.05)$

Fig. 1. Results of some examinations on the neuro-muscular function.

Solid cycle shows exposed group and open ones is control group.

Statistical significance was dicided by $t$-test.

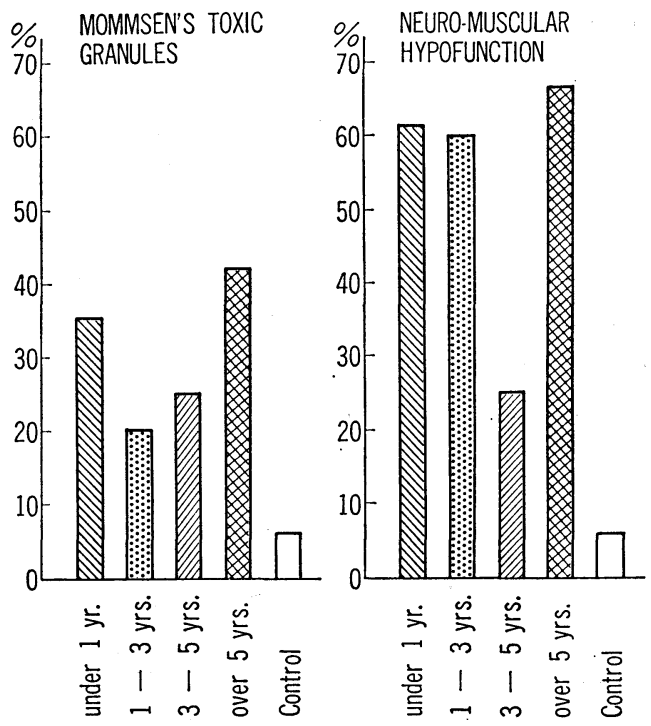

Fig. 2. Correlation between duration of exposure with toluene vapor and some appearance rate of abnormal findings.

Neuro-muscular hypofunctions were appraised by grasping power, decrease in tapping tempo and agility of the fingers.

No statistical significance was noted at $5 \%$ level in each items compared with other than control group. 


\section{T. MATSUSHITA, Y. ARIMATSU, A. UEDA, K. SATOH \& S. NOMURA}

\section{COMMENTS}

In order to obtain basic bata on TLV for toluene and early findings of toluene intoxication, health survey on 38 female workers exposed to low concentration of toluene vapor in a shoe making factory was conducted.

As for subjective symptoms, some complaints of such as headache, fatigue and others have been reported at concentration between 100 and $200 \mathrm{ppm} .{ }^{12,13)}$ Our results were almost similar to those studies, but dysmenorrhoea attracted our attention particularly. There are literatures that no significant physical and laboratory finding are observed at about $200 \mathrm{ppm}$ and under of toluene exposure. ${ }^{12 \sim 14)}$ On the contrary, a few investigations have noticed some findings such as prolongation of reaction time, decrease in pulse rate and systolic blood pressure, ${ }^{15)}$ disorders of peripheral neuro-muscular function,2) changes in adrenal glands, ${ }^{4)}$ and others. As we pointed out previously, appearance rate of Mommsen's toxic granules in peripheral neutrophiles increased markedly in spite of no significant difference were shown in other hemotological findings. The rest point of interest was on the neuro-muscular hypofunctions. These data are highly suggestive of early diagnosis for toluene intoxication.

As for concentrations of hippuric acid corresponding to level of toluene in the air, it has been proposed to be $3.5 \mathrm{~g} / \mathrm{l}$ (specific gravity 1.016 ) ${ }^{16}$ ) and $5.74 \pm 0.60 \mathrm{mg} / \mathrm{m} l^{15,17)}$ at $200 \mathrm{ppm}, 2.1 \pm 0.83 \mathrm{~g} / \mathrm{l}$ at $100 \mathrm{ppm}^{18)}$ and $2.81 \pm 0.71 \mathrm{mg} / \mathrm{m} l^{15,17)}$ at $100 \mathrm{ppm}$. Hippuric acid concentration examined in our survey was $3.26 \pm 0.82 \mathrm{mg} / \mathrm{ml}$, and it might be rather higher than $100 \mathrm{ppm}$ in comparison with those reports.

On the subject of TLV for toluene in the air, $200 \mathrm{ppm}$ is recommended by ACGIH, and others. ${ }^{19}$ ) On the other hand, $50 \mathrm{mg} / \mathrm{m}^{3}$ (approx. $13 \mathrm{ppm}$ ) of MAC is adopted in USSR, $200 \mathrm{mg} / \mathrm{m}^{3}(50 \mathrm{ppm})$ of TLV in Czechoslovakia and $100 \mathrm{ppm}$ of TLV in Japan Association of Industrial Health. There are few reports that $200 \mathrm{ppm}$ of TLV for toluene is rather high and should be decreased below $100 \mathrm{ppm}$ as a recommended TLV for toluene.

\section{ACKNOWLEDGEMENT}

Thanks are due to Dr. H. Kanagawa, Mrs. T. Ueda and Miss T. Ohmura for their technical assistance.

\section{REFERENCES}

1) Knox, J.W. and Nelson, J.R. (1966). Nerw Engl. J. Med., 275, 1494.

2) Matsumoto, T. (1971). Jap. J. Ind. Health, 13, 399 (in Japanese).

3) von Oettingen, W.F., Neal, P.A. and Donahue, D.D. (1942). J. Am. Med. Assoc., 118, 579. 


\section{TLV OF TOLUENE}

4) Takeuchi, Y. (1969). Ind. Health, 7, 31.

5) Michón, S. (1965). Med. Pracy, 16, 230.

6) Matsushita, T. (1966). Jap. J. Ind. Health, 8, 239 (in Japanese).

7) Johnstone, R.T. (1948). Occupational Medicine and Industrial Hygiene. The C.V. Mosby Co., St. Louis.

8) Browning, E. (1953). Toxicity of Industrial Organic Solvents. Her Majesty's Stationery Office, London.

9) Mommsen, H. (1927). Fol. Haematol., 34, 50.

10) Ogata, M., Sugiyama, K. and Moriyasu, H. (1962). Acta Med. Okayama, 16, 283.

11) Ogata, M., Tomokuni, K. and Takatsuka, Y. (1969). Brit. J. Ind. Med., 26, 330.

12) von Oettingen, W.F., Neal, P.A., Donahue, D.D., Svirbely, J.L., Baernstein, H.D., Monaco, A.R., Valaer, P.J. and Mitchell, J.L. (1942). Public Health Bull., No. 279.

13) Wilson, R.H. (1943). J. Am. Med. Assoc., 123, 1106.

14) Pendini, A., Andri, L. and Odescalchi, C.P. (1964). Fol. Med., 47, 1364.

15) Ogata, M., Tomokuni, K. and Takatsu, Y. (1970). Brit. J. Ind. Med., 27, 43.

16) Ikeda, M. and Ohtsuji, H. (1969). Brit. J. Ind. Med., 26, 244.

17) Ogata, M., Nagao, I. and Tomokuni, K. (1968). Jap. J. Ind. Health, 10, 64 (in Japanese).

18) Capellini, A. and Alessio, L. (1971). Med. Lav., 62, 196.

19) Cook, W.A. (1945). Ind. Med., 14, 936. 